\title{
ENZIMATIC HYDROLYSIS PROCESS FOR INCREASING GLUCOSE LEVELS FROM COCONUT HUSK WASTE
}

\author{
Dwi A. Anggorowati ${ }^{1 *}$, Sriliani ${ }^{2}$, Anis Artiyani ${ }^{3}$, Harimbi $\mathrm{S}^{4}$, Kevin $\mathrm{J}^{5}$ \\ 1,4,5 Department of Chemical Engineering, National Institute of Technology (ITN) Malang, \\ Indonesia \\ ${ }^{2}$ Department of Civil Engineering, National Institute of Technology (ITN) Malang, Indonesia \\ ${ }^{3}$ Department of Environmental Engineering, National Institute of Technology (ITN) Malang, \\ Indonesia
}

*Corresponding Email: anggoro_dwiana@ $\underline{\text { yahoo.com }}$

\begin{abstract}
Coconut husk waste is waste that has not been used optimally, generally only as a craft material. Seeing the composition of coconut husk, it has the potential to be used as an alternative fuel, one of which is to produce bioethanol products. The purpose of this research was to utilize coconut husk waste as raw material for bioethanol production and to assess the effect of the amount of enzymes and time of hydrolysis on the glucose levels produced. In this research, the authors focused on obtaining glucose levels from coconut husks by hydrolysis using cellulase enzymes with activity of $700 \mathrm{EGU} / \mathrm{g}$. The variations used in this research were the volume of cellulase enzymes $(2,3,4,5,6) \mathrm{ml}$ and the hydrolysis time $(4,8,12)$ hours. After the coconut husk undergo physical and chemical treatment using $10 \% \mathrm{NaOH}$, there is a decrease in lignin levels from $44 \%$ to $14 \%$ and there is an increase in cellulose levels from $24 \%$ to $38 \%$, and the use of a cellulase enzyme volume of $2 \mathrm{ml}$ with a hydrolysis time of 4 hours was more optimal with a glucose level of $0.32 \%$.
\end{abstract}

\section{Keywords: Coconut husk waste, glucose, cellulase enzymes, hydrolysis process}

\section{Introduction}

Fuel is a basic necessity for the community and its use tends to increase every year, while the source of petroleum fuel used today is getting low. Therefore, we need alternative materials that can be used as a substitute for petroleum. One of them is bioethanol. Bioethanol is a liquid fermented carbohydrate (starch) using the help of microorganisms. Bioethanol can be used as an alternative fuel to address current fuel needs.[1].

To produce bioethanol, there are several stages in general consisting of several series of processes, consisting of raw material preparation, delignification, hydrolysis, fermentation, and purification. However, in this research, only focused on the hydrolysis process with the aim of knowing the best glucose levels that can be produced [2]. The raw material preparation stage for making bioethanol can be obtained by selecting raw materials from various plants, either those that directly produce simple sugars such as sugar cane, sweet wheat or those that produce carbohydrates such as corn, cassava and wheat.

The second stage is delignification, this delignification process aims to reduce the lignin content found in raw materials which can generally be done using acid or alkaline solutions. The third stage is hydrolysis. Hydrolysis of cellulose and hemicellulose can be carried out chemically or enzymatically to produce glucose and xylose reducing sugar monomers [3].

One of the materials that can be used to make bioethanol is coconut husk waste

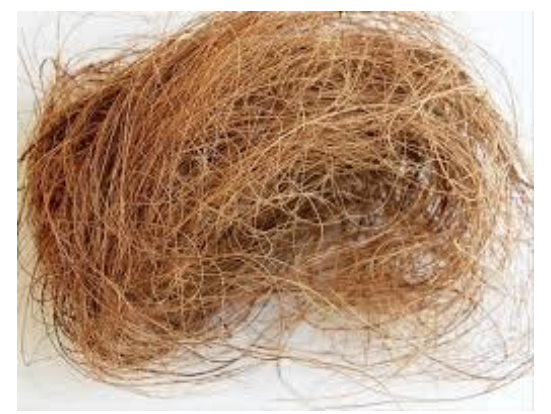

Figure 1 coconut husk

The availability of coconut husk waste is quite large, with the production of Indonesian coconut fruit averaging 15.5 billion grains/year or equivalent to 1.8 million tons of husk, and 3.3 million tons of husk dust. On average, one coconut fruit produces $0.4 \mathrm{~kg}$ of husk which contains $30 \%$ fiber. The chemical composition of 
old coconut coir is lignin $(45.8 \%)$, cellulose $(43.4 \%)$, hemicellulose $(10.25 \%)$, pectin $(3.0 \%)$. If we are able to convert cellulose to glucose, it will increase the conversion of coir coconut into ethanol [4].

According to Asyeni's research entitled "Utilization of Coconut Husk into Bioethanol with the Acid-Pretreatment Delignification Process". With variations in the concentration of $\mathrm{H}_{2} \mathrm{SO}_{4}$ and $\mathrm{CH}_{3} \mathrm{COOH}$ of $(1.3$, and $5 \%)$, at a temperature of $121 \mathrm{C}$ and with a delignification time of 60 minutes, the results of this research were that the lowest lignin levels were obtained using $\mathrm{H}_{2} \mathrm{SO}_{4}$ at a concentration of $5 \%$, it is $18.8125 \%$, whereas if you use $\mathrm{CH}_{3} \mathrm{COOH}$ the lowest lignin content is at a concentration of $5 \%$, it is $22.8965 \%$ [5].

According to Ade Irmawan's research entitled "Optimization of Reducing Sugar Levels in the Process of Hydrolysis of Corn Stalks Waste with Variations in Concentration of Cellulase Enzymes and Duration of Hydrolysis" explains that the results of reducing sugar levels in each time variable are different. Where the results of reducing sugar levels at variations of time $(5,6,7,8,9$ hours $)$ are directly proportional to variations in enzyme concentrations, $(2 ; 2.5$; $3 ; 3.5 ; 4 \%$ ) which has continued to increase where the sugar yield The best reduction was at a concentration of $4 \%$, namely $1596.7 \mathrm{mg} / \mathrm{L}$, but at a concentration of $3 \%$ enzyme, the result of reduced sugar decreased compared to the previous enzyme concentration $(2 \%$ and $2.5 \%)[5]$.

According to the research of Betaria entitled "Making Bioethanol from Coconut Husk Waste with Acid Hydrolysis and Fermentation Methods Using Yeast Tape". During the hydrolysis process using acid, the variation in the concentration of $\mathrm{HCl}$ used is $10 \%, 20 \%, 30 \%$. So that, the resulting glucose levels are $17.4 ; 14.27$; and $11.5 \%$. The best result from the hydrolysis process is using $\mathrm{HCl}$ at a concentration of $10 \%$, which is $17.4 \%$ which is used for the next fermentation stage

\section{Research Methodology}

\subsection{Experimental}

The research was conducted at the Chemical Analysis Laboratory of ITN Malang. The following are fixed variables for the Delignification Process: 100 gr coconut husk size 80 mesh, $10 \% \mathrm{NaOH}$ concentration, 28 hours Delignification time, $28^{\circ} \mathrm{C}$ heating temperature, while the fixed variables for the hydrolysis process: Type of cellulase enzyme, 10 grams of coconut husk, $\mathrm{pH} \mathrm{5,} \mathrm{the} \mathrm{hydrolysis} \mathrm{temperature}$ is $37^{\circ} \mathrm{C}$. Variable changes were hydrolysis time of $4,8,12$ hours and variations in the number of enzymes: $2 \mathrm{~mL}, 3 \mathrm{~mL}, 4 \mathrm{~mL}, 5 \mathrm{~mL}, 6 \mathrm{Ml}$ [7].

\subsection{The materials and equipment used:}

The tools used are as follows: 80 mesh sieve, Basin, Beakerglass, sample bottles, Erlenmeyer, Furnace, LPG gas, watch glasses, stirring glasses, stove, three-neck flask, measuring flask, baking sheet, magnetic stirrer, grinding machine, mortar, oven, Pans, Dropper Pipettes, Volume pipettes, Knives, Thermometers, Scales The materials used are as follows Aquadest, $\mathrm{NaOH}$, $\mathrm{H}_{2} \mathrm{SO}_{4}$, cellulase enzymes, coconut husk.

\subsection{Study Procedure}

The research procedure carried out includes three stages, they are material preparation, delignification process and the last stage is the hydrolysis process, which are as follows:

\subsection{Material Preparation}

Coconut coir is crushed roughly then analyzed for cellulose, hemicellulose, and lignin content before physical treatment (Chesson method), coconut husk is then cleaned first using aquadest, then dried in an oven at $105^{\circ} \mathrm{C}$ for 24 hours to remove the moisture content, then The dry coconut husk is blended into a powder with a uniform size of $\pm 80 \mathrm{mesh}$, then stored in a desiccator dialate. And cellulose, hemicellulose, and lignin analysis were performed (Chesson method).

\subsection{Process of Delignification}

Coconut coir powder weighed 100 grams is put into a beaker glass, add a $10 \%$ concentration of $\mathrm{NaOH}$ solution, and soak the sample solution at $28^{\circ} \mathrm{C}$ for 28 hours, filter the delignification results and neutralize it to $\mathrm{pH} 7$, dry again using an oven with a temperature of $105^{\circ} \mathrm{C}$ for 12 hours, followed by a lignin, cellulose and hemicellulose analysis procedure. All work is done twice (duplo)

\subsection{Enzyme Hydrolysis}

Taking the best sample (coconut husk) from the delignification process, weighing the sample as much as 10 grams, inserting the weighed sample into Erlenmeyer, adding enzymes with variations of $2 \mathrm{~mL}, 3 \mathrm{~mL}, 4 \mathrm{~mL}, 5 \mathrm{~mL}$, and $6 \mathrm{~mL}$ into each Erlenmeyer, then add $100 \mathrm{~mL}$ of water, the hydrolysis process is carried out with a time 
variation of 4 hours, 8 hours, and 12 hours, the hydrolysis process is carried out at $37^{\circ} \mathrm{C}$ at $\mathrm{pH} 5$, after the hydrolysis process is finished, it is followed by taking samples to analyze the glucose levels.

\section{Results and Discussions}

\subsection{Delignification Process}

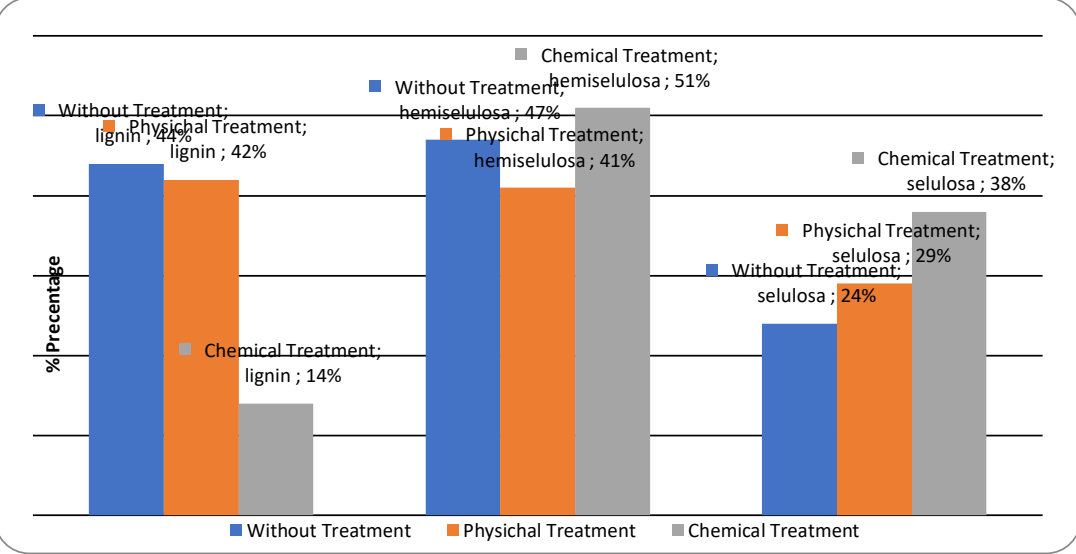

Figure 2 Graph Comparison of hemicellulose, cellulose, and lignin levels with initial conditions, physical treatment, and chemical treatment

In the graph above, it shows that the coconut husk is not treated, the hemicellulose content is $47 \%$, $24 \%$ cellulose and $44 \%$ lignin, then when the coconut husk is physically treated with coir it is milled then sieved using an 80 mesh sieve. The data obtained from the data obtained hemicellulose $41 \%, 29 \%$ cellulose, and $42 \%$ lignin from the data proving that physical treatment can reduce lignin levels. After physical treatment is carried out, it is followed by chemical treatment with the delignification method using $10 \% \mathrm{NaOH}$. 80 mesh coconut fiber soaked for 28 hours using $10 \% \mathrm{NaOH}$ at room temperature with a pressure of $1 \mathrm{~atm}$.
The delignification process aims to remove lignin, reduce the crystallinity of cellulose, and increase the porosity of the material. The following is a graph comparing the levels (\%) of hemicellulose, cellulose, and lignin with initial conditions, physical treatment and chemical treatment. 
Unlike cellulose, hemicellulosic polyscharides are amorphous and less branched in structure, so their solubility potential is very different. Hemicellose can be separated from cellulose by alkaline because the bonds are weak so that it is easily hydrolyzed [11].

The cellulose content increased from the initial $24 \%$, then after physical treatment the cellulose content increased to $29 \%$, and after chemical treatment, the cellulose content increased to $38 \%$. This increase in cellulose levels is in accordance with Agustini's theory which states that the amount of lignin and cellulose is inversely related [12]. The more lignin levels are broken down, the cellulose levels will increase. This is because the lignin layer that protects cellulose has been reduced, so that cellulose can appear optimally. And in the following picture is a picture of the chemical delignification process in coconut husk samples.

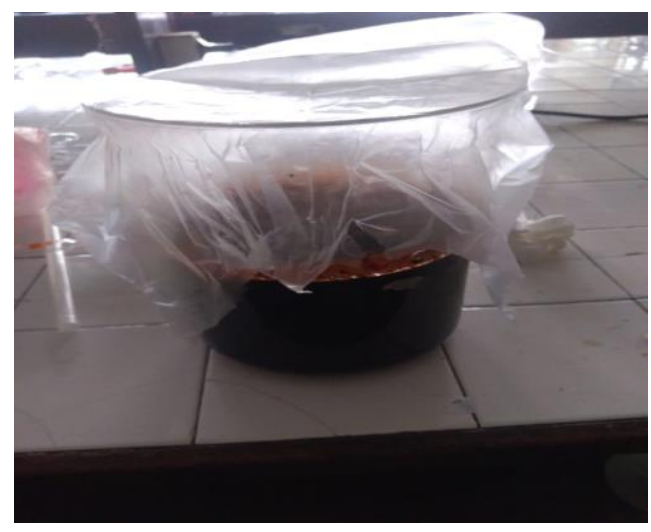

Figure 4 Delignification Process

And the picture below is a mechanism for breaking the bond between lignin and cellulose by $\mathrm{NaOH}$ compounds.

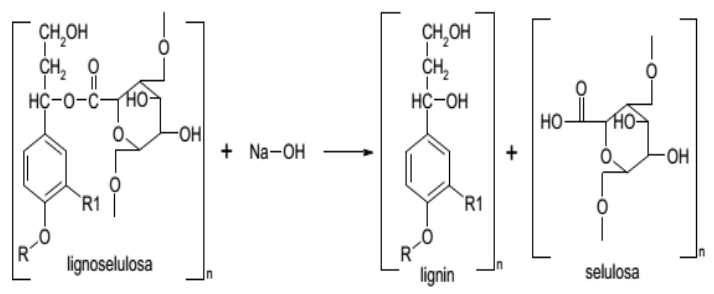

Figure 5 Breaking of the bonds between lignin and cellulose by $\mathrm{NaOH}$ [13]

The $\mathrm{OH}^{-}$ion from $\mathrm{NaOH}$ will break the bonds from the basic lignin structure while the $\mathrm{Na}^{+}$ion will bind with lignin to form sodium phenolics. This phenolic salt is soluble [8]. The results of delignification of coconut husk are in the form of a residue and a filtrate called black liquor. The black liquor is blackish brown. The mechanism of breaking lignin compounds is where the base groups of the cooking solution $(\mathrm{NaOH})$ degrade or attack alpha and beta lignin. The degraded lignocellulose is unstable, so it triggers condensation which causes the breakage of lignin bonds from hemicellulose and cellulose [14].

\subsection{Hydrolysis Process}

Hydrolysis is the process of breaking down complex sugars into simple sugars. In the hydrolysis process, cellulose is converted into cellobiose or sucrose and then into simple sugars such as glucose. Meanwhile, the result of hydrolysis of the hemicellulose component is a mixture of simple sugars such as glucose, galactose, xylose, and arabinose [15]. In complete hydrolysis cellulose will produce glucose, while hemicellulose produces several sugar monomers pentose (C5) and hexose $\left(\mathrm{C}_{6}\right)$. Hydrolysis can be carried out chemically (acid) or enzymatically [16].

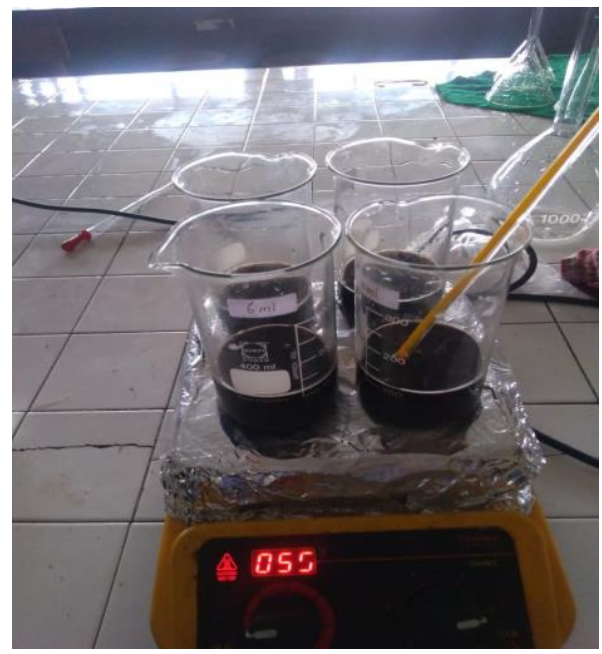

Figure 6 Hydrolysis Process

Basically, the mechanism of cutting the bond chain by cellulase enzymes is very complex because it involves the synergy of the work of 3 major components, namely endo-1.4- $\beta$-Dglucanase which functions to break cellulose bonds randomly by starting a random attack on the internal side of the amorphous region of the cellulose fiber so that the side that is open can be attacked by cellobiohydrolase. Then the action of ekso- $\beta$-1.4-glucanase which cuts the ends of the individual chains of cellulose. ekso- $\beta-1.4-$ glucanase or called cellobiohydrolase attacks the non-reducing exterior of cellulose so that cellobiose is produced as its main structure. 
Next is the work of $\beta$-glucosidase which functions to cut cellobiose into glucose molecules.

Cellulase enzymes can convert unsubstituted cellulose into cellobiose which is then further hydrolyzed with $\beta$-glucosidase. Breaking this bond will produce oligosaccharide derivatives of cellulose, which are finally converted into glucose monomers [17].

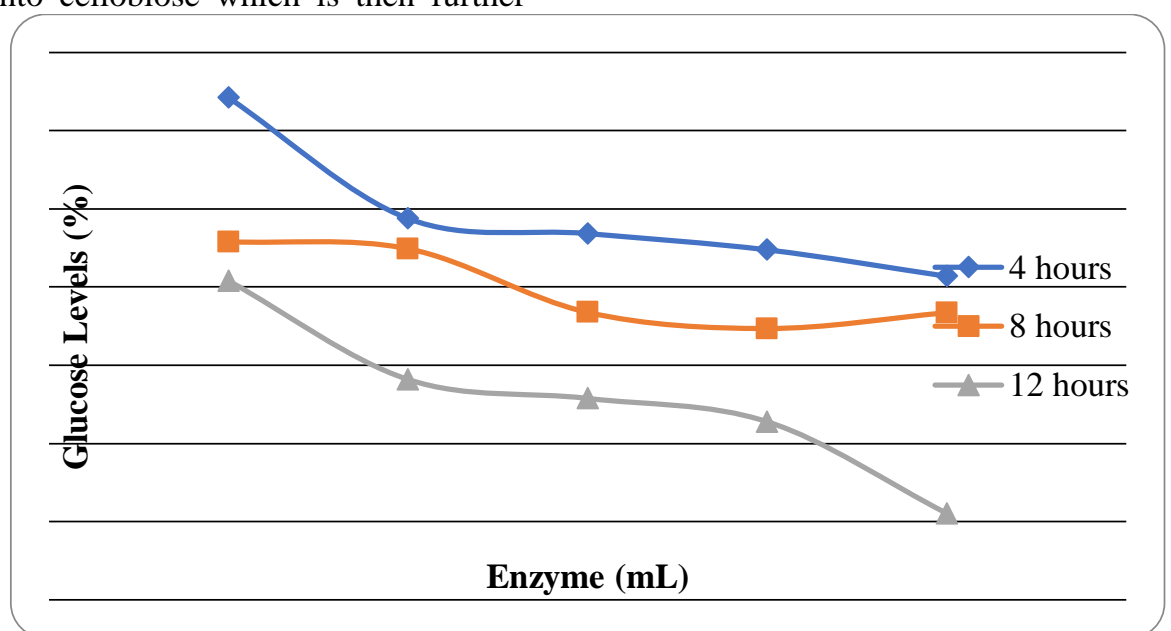

Figure 7 Graphic analysis of glucose levels against enzymes and hydrolysis time

Figure 7 shows that the results of glucose levels at each time variable are different. Where the results of glucose levels at each time variable have decreased. The highest glucose level was at 4 hours with the amount of enzyme of $2 \mathrm{ml}$, it is $0.3211 \%$. This is not in accordance with the theory which says that the longer the hydrolysis time, the more glucose levels will be produced because the more time for the breakdown of cellulose into glucose. This is due to several other factors that cause the results of glucose levels to tend to be small and decrease among them, the first is because the temperature during the hydrolysis process is not constant, this is due to the use of hotplates with a temperature range of $37-40^{\circ} \mathrm{C}$, the second factor is time, time. less needed to make cellulase enzymes work optimally. Hydrolysis using enzymes tends to take longer than using acids or alkalis. Some of the disadvantages of enzymatic hydrolysis include that it takes a longer time, and the action of the enzyme is inhibited by the product [15].

\section{Conclusions}

Based on the results of observations and calculations that we have done during the study, a conclusion can be drawn

- After coconut fiber undergoes physical and chemical treatment using $10 \% \mathrm{NaOH}$, there is a decrease in lignin levels from $44 \%$ to $14 \%$ and there is an increase in cellulose levels from $24 \%$ to $38 \%$.
- The use of cellulose enzyme volume of $2 \mathrm{ml}$ with a hydrolysis time of 4 hours is more optimal than the hydrolysis process using cellulase enzymes with a volume of cellulose enzymes of $3 \mathrm{ml}, 4 \mathrm{ml}, 5 \mathrm{ml}, 6 \mathrm{ml}$ with a glucose level of $0.32 \%$.

\section{Suggestions}

In future researches, it is more concerned with factors that influence the enzyme hydrolysis process. Using a more constant temperature, and for hydrolysis using enzymes must be carried out for a longer time.

\section{Reference}

[1] Retno, Dyah Tri. (2011). Making Bioethanol from Banana Peels, Department of Chemical Engineering: UPN "Veteran" Jatim

[2] Anggorowati DA, Minah FN, Artayani A, Mustiadi L (2020) Early Study of Biocharcoal Quality From Poultry Livestock Waste. Journal Of Sustainable Technology And Applied Science (JSTAS) 1:7-12

[3] Purwati, dkk. (2015). Effect of Temperature and Nutrient Addition in the Fermentation Process for Making Bioethanol from Coconut Coir, Department of Chemical Engineering: The National Institute of Technology Malang 
[4] Hanum, Astuti. (2013). Growth Effectiveness of White Oyster Mushroom (Pleurotusostreatus) with Variations of Sengon Wood (Paraserianthes falcataria) and Coconut Coir (Cocos nucifera) Media. Faculty of Mathematics and Natural Sciences: Sepuluh Nopember Institute of Technology

[5] Miftahul Jannah, Asyeni. (2017). Utilization of Coconut Coir Into Bioethanol Using Delignification Acid-Pretreatment Process. Department of Chemical Engineering: Sriwijaya University

[6] Ade Irmawan, dkk. (2013).Optimization of Reduced Sugar Levels in the Hydrolysis Process of Corn Stalk Waste with Variations in the Concentration of Cellulase Enzymes and Hydrolysis Time, Department of Chemical Engineering: The National Institute of Technology Malang.

[7] Betaria Kusuma Dewi, dkk. (2013). Making Bioethanol from Coconut Coir Waste Using Acid Hydrolysis and Fermentation Methods Using Yeast Tape, Department of Chemical Engineering : The National Institute of Technology Malang

[8] Julfana, Rika. (2012). Enzymatic Hydrolysis of Cellulose from Sago Dregs Using Cellulase Mixtures of Trichoderma Reesei and Aspergillus Niger, Tanjungpura University.

[9] Safaria, Selviza. (2013). Effectiveness of Cellulase Enzyme Mixture From Aspergillus Niger And Trichoderma Reesei In Hydrolyzing Coconut Coir Substrate, Tanjungpura University.

[10] Susanti,R. (2017). Enzyme Technology, Yogyakarta

[11] Placket, David. (2011). Biopolymers: New Material For Sustainable Films And Coating, Amerika: Wiley Publishing.

[12] Agustini, Luciasih. (2015). Effect of Delignification Treatment on Cellulose Hydrolysis and Ethanol Production from Berlignocellulosic Waste. Jakarta.

[13] Fengel D., Wegener, G. (1995), Wood Chemistry Ultrastructure, Reactions, Yogyakarta, Gajah mada University Press.

[14] Lubis Afni Ariani. (2007). Isolation of Lignin and Black Liquor (Black Liquor) Cooking Process for Soda Pulp and Sulfate Pulp (Kraft)", Faculty of Agricultural Technology, Bogor Agricultural Institute.

[15] Fuadi, AM.(2015). Effect of Temperature and $\mathrm{Ph}$ on the Amount of Yield (Glucose Levels) Produced in the Enzymatic Hydrolysis Process of Paper Waste, Surakarta.
[16] Seftian, Deky. (2012). Making Ethanol From Banana Peels Using Enzymatic Hydrolysis And Fermentation Methods, Sriwijaya University.

[17] Kodri. (2013). Utilization of Cellulase Enzymes from Trichoderma Reseei and Aspergillus Niger as Enzymatic Hydrolysis Catalysts for Rice Straw Using Microwave Pretreatment. Malang. 